\title{
Effect of Different Levels of Fertilizer on Growth and Yield of Okra
}

\author{
A. A. Shelke ${ }^{1}$, S. B. Wadatkar ${ }^{1}$ and R. M. Beldar ${ }^{2 *}$ \\ ${ }^{1}$ Department of Irrigation and Drainage Engineering, ${ }^{2}$ Department of Soil and Water \\ Conservation Engineering, Dr. PDKV, Akola, India \\ *Corresponding author
}

\section{A B S T R A C T}

\begin{tabular}{|l|}
\hline Ke y w o r d s \\
Okra, Vegetable, \\
India, Nigeria, \\
Pakistan, \\
Cameroon, Iraq
\end{tabular}

The present study was carried out to study the effect of different fertilizer levels on growth and yield of okra crop at Research Farm of Department of Irrigation and Drainage Engineering, College of Agriculture Engineering and Technology, Dr. PDKV, Akola during 03 Dec 2016 to 04 Mar 2017. The experimental was laid in randomized block design (RBD) with seven treatments and three replications $\left(\mathrm{I}_{1} \mathrm{~T}_{1-60 \%} \mathrm{ET}_{\mathrm{c}}\right.$ with Polyethylene mulch and $60 \% \mathrm{RDF}, \mathrm{I}_{1} \mathrm{~T}_{2}-60 \% \mathrm{ET}_{\mathrm{c}}$ with Polyethylene mulch and $80 \% \mathrm{RDF}$, $\mathrm{I}_{1} \mathrm{~T}_{3}-60 \% \mathrm{ET}_{\mathrm{c}}$ with Polyethylene mulch and $100 \% \mathrm{RDF}, \mathrm{I}_{2} \mathrm{~T}_{1-} 80 \% \mathrm{ET}_{\mathrm{c}}$ with Polyethylene mulch and $60 \%$ RDF, $\mathrm{I}_{2} \mathrm{~T}_{2-} 80 \% \mathrm{ET}_{\mathrm{c}}$ with Polyethylene mulch and $80 \% \mathrm{RDF}, \mathrm{I}_{2} \mathrm{~T}_{3-8} 80 \% \mathrm{ET}_{\mathrm{c}}$ with Polyethylene mulch and 100\% RDF and control-100\% $\mathrm{ET}_{\mathrm{c}}$ without Polyethylene mulch and $100 \%$ RDF).Seeds of okra (Abelmoschus esculentus L.) of the variety Phule Utkarsha were sown with seed rate of $8 \mathrm{kgha}^{-1}$. The recommended fertilizer dose of 100:50:50 N: P: K Kg/ha and as per treatments was given through fertigation in five equal splits. All the growth and yield parameters were found maximum under treatment $I_{2} T_{3}$ while the quality parameter was found maximum for treatment $I_{2} T_{2}$. The treatment $I_{2} T_{3}$ $\left(80 \% \mathrm{ET}_{\mathrm{c}}\right.$ with $100 \% \mathrm{RDF}$ and plastic mulch) has given maximum yield of $116.26 \mathrm{q} / \mathrm{ha}$. The lowest yield was observed under control treatment $(10.15 \mathrm{q} / \mathrm{ha})$. Okra crop should be grown under polyethylene mulch and drip irrigation at $80 \%$ crop evapotranspiration and $100 \%$ RDF for highest production.

\section{Introduction}

Okra, Abelmoschus esculentus L. Moench is a popular vegetable in tropical and sub-tropical countries of the world grown for its pod. It is a member of the hibiscus family, Malvaceae and has the typical floral characteristics of that family. Originating from Africa, it is now widely distributed in the tropics including and most popular in India, Nigeria, Pakistan,
Cameroon, Iraq and Ghana. The area and production of okra in world is 1.83 million hector and 9.62 million tons respectively with the productivity of 5.26 tons per hector. India is the largest producer of okra in world with area of 0.53 Million hector, production of6.35 million tons and productivity of 11.91 tons per hector (NHB, 2017). Fertilizer is a material that is added to the soil to supply one or more elements required for plant growth and 
development (Masarirambi et al., 2012). The application of fertilizer is necessary for enhancing the soil nutrient status and increasing crop yield. Okra requires nutrients such as nitrogen $(\mathrm{N})$, phosphorus $(\mathrm{P})$, potassium $(\mathrm{K})$, calcium $(\mathrm{Ca})$, sodium $(\mathrm{Na})$ and Sulphur (S) for fertility maintenance and crop production. These nutrients are specific in function and must be supplied to plants at the right time and at the right quantity. Lack of sufficient amounts of these nutrients result in poor performance of the crop with growth been affected resulting to low yield (Shukla and Naik, 1993). With the different concentrations of the NPK fertilizers, the yield and growth rate of the plant may also be different, thus there is a need to investigate the effects of different level of NPK fertilizers on growth and yield of okra. The broad objective of this research is to assess the effect of different levels of NPK fertilizer and to study the most appropriate quantity or level of fertilizer for the optimum growth and yield of okra.

\section{Materials and Methods}

A field study was carried outduring 03 Dec 2016 to 04 Mar 2017 at the field of the Department of Irrigation and Drainage Engineering, Dr. Panjabrao Deshmukh Krishi Vidyapeeth, Akola, Maharashtra, India to study the effect of different level of fertilizers on growth and yield of okra. The climatological data (data on the daily pan evaporation) was collected from Agro Meteorology Centre Department of Agronomy, Dr. PDKV. Akola during the period of investigation

\section{Experimental site (location and climate)}

Akola is situated in Western Vidarbha region of Maharashtra state and comes under subtropical zone, at an altitude of $307.415 \mathrm{~m}$ above mean sea level (MSL) at the intersection of $20^{\circ} 40^{\prime}$ north latitude and $77^{0} 02^{\prime}$ east longitude. The climate of the area is semi-arid, characterized by three distinct seasons; mainly summer being hot and dry from March to May, the warm and rainy monsoon from June to October and winter with mild cold from November to February. The mean annual maximum and minimum temperature are $48.23^{\circ} \mathrm{C}$ and $22.05^{\circ} \mathrm{C}$ in summer and $32.88^{\circ} \mathrm{C}$ and $14.35^{\circ} \mathrm{C}$ in winter respectively. Average annual precipitation is $760 \mathrm{~mm}$.

\section{Soil analysis}

To study the physical and chemical properties of soil four samples were collected from the corner and one from the centre of the field at depths of $10 \mathrm{~cm}, 20 \mathrm{~cm}$ and $30 \mathrm{~cm}$ with the help of auger. Soil samples were tested in laboratory of Department of Agricultural Chemistry and Soil Science, Dr. PDKV, Akola. The results are presented in Table 1.The soil moisture constants in terms of field capacity and permanent wilting point were determined using the standard procedure suggested by Michael (1978) and presented in Table 2.

\section{Experiment design and layout}

The experimental was laid in randomized block design (RBD) with seven treatments and three replications, the treatments are $\mathrm{I}_{1} \mathrm{~T}_{1^{-}}$ $60 \% \mathrm{ET}_{\mathrm{c}}$ with Polyethylene mulch and $60 \%$ $\mathrm{RDF}, \mathrm{I}_{1} \mathrm{~T}_{2}-60 \% \mathrm{ET}_{\mathrm{c}}$ with Polyethylene mulch and $80 \% \quad \mathrm{RDF}, \quad \mathrm{I}_{1} \mathrm{~T}_{3^{-}} \quad 60 \% \quad \mathrm{ET}_{\mathrm{c}}$ with Polyethylene mulch and $100 \% \mathrm{RDF}, \mathrm{I}_{2} \mathrm{~T}_{1^{-}}$ $80 \% \mathrm{ET}_{\mathrm{c}}$ with Polyethylene mulch and $60 \%$ $\mathrm{RDF}, \mathrm{I}_{2} \mathrm{~T}_{2}-80 \% \mathrm{ET}_{\mathrm{c}}$ with Polyethylene mulch and $80 \% \quad \mathrm{RDF}, \mathrm{I}_{2} \mathrm{~T}_{3^{-}} \quad 80 \% \quad \mathrm{ET}_{\mathrm{c}}$ with Polyethylene mulch and 100\% RDF and Control - $100 \% \mathrm{ET}_{\mathrm{c}}$ without Polyethylene mulch and $100 \%$ RDF. A field of size $31 \mathrm{~m} \mathrm{x}$ $15.5 \mathrm{~m}$ was selected for experimental studies. The field was divided into seven equal 
treatment of $55.8 \mathrm{~m}^{2}$. The single treatment was again divided in to three replication of equal size $(3.6 \times 4.5 \mathrm{~m})$ with a buffer strip of $0.3 \mathrm{~m}$ between giving plant density of 90 plants per plot. The plastic mulch film (silver up and black down) of $50 \mu \mathrm{m}$ thickness was used to cover six treatments, and control treatment was kept uncovered.

Seeds of okra (Abelmoschus esculentus L.) of the variety Phule Utkarsha were sown with seed rate at $8 \mathrm{kgha}^{-1}$. The field was ploughed and levelled properly.

The recommended fertilizer dose of 100:50:50 $\mathrm{N}$ : P: $\mathrm{K} \mathrm{Kg} / \mathrm{ha}$ and according to different treatments was given through fertigation in five equal splits. The schedule of fertigation is given in Table 3.

Before sowing, common irrigation was applied on $1^{\text {st }}$ December 2016 to the field to bring the soil to field capacity for better germination. After sowing on $3^{\text {rd }}$ December, 2016, the irrigation was provided on every alternate day by drip irrigation at 60,80 and 100 , per cent $\mathrm{ET}_{\mathrm{c}}$ levels.

\section{Results and Discussion}

The study of effect of different fertilizer levels on growth and production of okra was carried out by observing and recording the growth, yield and quality parameters of okra crop.

The growth parameters (i.e. plant height, number of branches and canopy cover) were recorded 30, 60 and 90 days after germination. The yield parameters (i.e. number of fruits per plant, average yield per plant and fruit yield from each plot) and the quality parameter (i.e. length of fruit) was recorded at the time of harvest. The field observations on each biometric character was taken and analyzed. The results are discussed below and presented in Table 4.

\section{Biometric observation}

\section{Height of the plant $(\mathrm{cm})$}

From the Table 5 it can be seen that the highest plant height $(109.67 \mathrm{~cm})$ was observed at $90 \mathrm{DAS}$ for the treatment $\mathrm{I}_{2} \mathrm{~T}_{3}\left(80 \% \mathrm{ET}_{\mathrm{c}}\right.$ with $100 \%$ RDF and PM). Also the lowest plant height $(37.13 \mathrm{~cm})$ was observed for control treatment $\left(100 \% \mathrm{ET}_{\mathrm{c}}\right.$ without mulch and with $100 \% \mathrm{RDF}$ ) at 90 DAS respectively. After 90 DAS treatments $\mathrm{I}_{2} \mathrm{~T}_{3}$ and $\mathrm{I}_{2} \mathrm{~T}_{2}$ were statistically at par and both were significantly superior over $\mathrm{I}_{1} \mathrm{~T}_{1}, \mathrm{I}_{1} \mathrm{~T}_{2}, \mathrm{I}_{1} \mathrm{~T}_{3}, \mathrm{I}_{2} \mathrm{~T}_{1}$ and control treatments.

\section{Number of branches per plant}

It can be observed from the Table 5 maximum number of branches (14.67) were observed in treatment $\mathrm{I}_{2} \mathrm{~T}_{2}$ followed by treatment $\mathrm{I}_{2} \mathrm{~T}_{3}(14.4)$ and $\mathrm{I}_{1} \mathrm{~T}_{3}(13.06)$ respectively. The minimum number of branches (7.8) were observed in control treatment $\left(100 \%\right.$ ET $_{\mathrm{c}}$ with $100 \%$ RDF and without PM). The treatment $\mathrm{I}_{2} \mathrm{~T}_{2}$ and $\mathrm{I}_{2} \mathrm{~T}_{3}$ were statistically at par with each other and both were superior over tretments $\mathrm{I}_{1} \mathrm{~T}_{1}, \mathrm{I}_{1} \mathrm{~T}_{2}, \mathrm{I}_{1} \mathrm{~T}_{3}, \mathrm{I}_{2} \mathrm{~T}_{1}$ and control.

\section{Canopy cover $\left(\mathrm{cm}^{2}\right)$}

From Table 5 it is seen that at 90 DAS treatment $\mathrm{I}_{2} \mathrm{~T}_{3}$ recorded highest canopy cover $\left(2873.91 \mathrm{~cm}^{2}\right)$; significantly lowest canopy cover was found in control treatment $(564.87$ $\mathrm{cm}^{2}$ ). After 90 DAS treatments $\mathrm{I}_{2} \mathrm{~T}_{3} \& \mathrm{I}_{2} \mathrm{~T}_{2}$ were statistically at par and both were significantly superior over $\mathrm{I}_{1} \mathrm{~T}_{1}, \mathrm{I}_{1} \mathrm{~T}_{2}, \mathrm{I}_{1} \mathrm{~T}_{3}, \mathrm{I}_{2} \mathrm{~T}_{1}$ and control treatments.

\section{Average yield of okra per plant (gm)}

From the above Table 5 it is seen that highest yield of fruit weight was recorded in treatment $\mathrm{I}_{2} \mathrm{~T}_{3}(408.96 \mathrm{gm})$ followed by $\mathrm{I}_{2} \mathrm{~T}_{2}(394.69 \mathrm{gm})$, $\mathrm{I}_{2} \mathrm{~T}_{1}(371.26 \mathrm{gm}), \mathrm{I}_{1} \mathrm{~T}_{3}(368.18 \mathrm{gm})$ and the 
lowest value of fruit weight was observed for the control treatment $(129.46 \mathrm{gm})$. Treatments $\mathrm{I}_{2} \mathrm{~T}_{3}, \mathrm{I}_{2} \mathrm{~T}_{2}, \mathrm{I}_{2} \mathrm{~T}_{1}$ and $\mathrm{I}_{1} \mathrm{~T}_{3}$ were at par and significantly superior over $\mathrm{I}_{1} \mathrm{~T}_{2}, \mathrm{I}_{1} \mathrm{~T}_{1}$ and control treatments.

\section{Yield per treatment}

The treatment $\mathrm{I}_{2} \mathrm{~T}_{3}\left(80 \% \mathrm{ET}_{\mathrm{c}}\right.$ with $100 \% \mathrm{RDF}$ and plastic mulch) has given maximum yield of $116.26 \mathrm{q} / \mathrm{ha}$. The lowest yield was observed under control treatment (10.15 q/ha). Treatments $\mathrm{I}_{2} \mathrm{~T}_{3}, \quad \mathrm{I}_{2} \mathrm{~T}_{2}$ and $\mathrm{I}_{1} \mathrm{~T}_{3}$ were found statistically at par and significantly superior over $\mathrm{I}_{1} \mathrm{~T}_{1}, \mathrm{I}_{1} \mathrm{~T}_{2}, \mathrm{I}_{2} \mathrm{~T}_{1}$ and control treatments.

\section{Number of fruits per plant}

Table 5 shows that the treatment $\mathrm{I}_{2} \mathrm{~T}_{3}\left(80 \% \mathrm{ET}_{\mathrm{c}}\right.$ with $100 \%$ RDF and plastic mulch) yielded with a highest average number of fruits per plant (19.07) followed by treatment $\mathrm{I}_{2} \mathrm{~T}_{2}(80 \%$ $\mathrm{ET}_{\mathrm{c}}$ with $80 \% \mathrm{RDF}$ and plastic mulch) with 18.66 fruits per plant. Treatments $\mathrm{I}_{2} \mathrm{~T}_{3}, \mathrm{I}_{2} \mathrm{~T}_{2}$, $\mathrm{I}_{2} \mathrm{~T}_{1}$ and $\mathrm{I}_{1} \mathrm{~T}_{3}$ were found statistically at par and were significantly superior overI $\mathrm{T}_{1}, \mathrm{I}_{1} \mathrm{~T}_{2}$ and control treatments.

\section{Mean fruit length}

Table 5 shows that the highest length of fruit $(12.80 \mathrm{~cm})$ was recorded in treatment $\mathrm{I}_{2} \mathrm{~T}_{2}$ and lowest in control treatment (10.32 $\mathrm{cm})$. TreatmentsI $\mathrm{I}_{2} \mathrm{~T}_{2}$ and $\mathrm{I}_{2} \mathrm{~T}_{3}$ were at par and also found superior over $\mathrm{I}_{1} \mathrm{~T}_{1}, \mathrm{I}_{1} \mathrm{~T}_{2}, \mathrm{I}_{1} \mathrm{~T}_{3}, \mathrm{I}_{2} \mathrm{~T}_{1}$ and control treatments.

All the growth and yield parameters were found maximum under treatment $\mathrm{I}_{2} \mathrm{~T}_{3}$ and quality parameter i.e. length of fruit was found maximum for treatment $\mathrm{I}_{2} \mathrm{~T}_{2}$. The treatment $\mathrm{I}_{2} \mathrm{~T}_{3}\left(80 \% \mathrm{ET}_{\mathrm{c}}\right.$ with $100 \% \mathrm{RDF}$ and plastic mulch) has given maximum yield of 116.26 $\mathrm{q} / \mathrm{ha}$. The lowest yield was observed under control treatment $(10.15 \mathrm{q} / \mathrm{ha})$. Okra crop should be grown under polyethylene mulch and drip irrigation at $80 \%$ crop evapotranspiration and $100 \% \mathrm{RDF}$ for highest production.

\section{References}

Anonymous, (2017). Indian Horticulture Database 2016-2017 -NHB.

Biswas SK, Akanda AR, Rahman MS and Hossain MA, 2015. Effect of drip irrigation and mulching on yield, water-use efficiency and economics of tomato. Plant Soil Environ. 61(3): 97102.

BhanuRekha K, Reddy MG, Mahavishnan K and Bhanu Murthy VB 2005. Nitrogen and water use efficiency of Bhendias influenced by drip fertigation. Journal of Tropical Agriculture 43(1-2): 43-46.

Bhardwaj RL, 2013. Effect of mulching on crop production under rainfed condition - a review. Agri. Reviews, 34(3): 188-197, 2013.

Elhindi K, El-Hendawy S, Abdel-Salam E, Mukhtar Ahmed and Abdallah Elgorban, 2016. Impacts of fertigation via surface and subsurface drip irrigation on growth rate, yield and flower quality of Zinnia elegans. Soil and Plant Nutrition - Article, Bragantia, Campinas, 75(1): 96-107, 2016.

Ganesh Babu R, BhaskarRao I, and Raja Kumar KN, 2015. Response of okra to different levels of drip irrigation on growth, yield and water use efficiency. International Journal of Agricultural Engineering, 8(1): 47-53.

Masarirambi, M.T, Hlawe, M.M., Oseni, O.T. and Sibiya, T.E. (2010).Effects of organic fertilizers on growth, yield, quality and sensory evaluation of red lettuce (Luctuca sativa L.) Veneza Roxa. Agriculture and Biology Journal of North America. 1 (6): 1319-1324.

Punamhoro PBN, Chowdhary BM and 
Kandeyang S, 2003. Performance of different irrigation methods in okra (Abelmoschuses culentus (L.) Moench). J. Res. BAU. 15(2): 205210.

Pushpavalli R, Arulthasan T and Kandaswamy KG, 2014. Growth, nutrient uptake and yield of Okra (Abelmoschus esculentus (L) Moench) as influenced by organic and inorganic $\mathrm{K}$ fertilizers. Academia Journal of Agricultural Research. 2(10): 203-206, October 2014.

Salunkhe R, Bhamare D and Mavale D, 2015. Response of different irrigation and fertigation levels on growth and yield of okra (Abelmoschus esculentus L. Moench). Int. J. of Trop. Agri., 33(4).

Sharma P, Kaushal A, Singh A and Garg S, 2015. Growth and Yield attributes of
Okra under Influence of Drip Irrigation. Int. Journal of Engineering Research and Applications. 6(2) (Part 5): 85-91.

Sharma P, Kaushal A, Singh A and Garg S, 2015. Growth and Yield attributes of Okra under Influence of Drip Irrigation. Int. Journal of Engineering Research and Applications. 6(2) (Part 5): 85-91.

Singh B, Kumar M and Mehto SP (2007). Advancing bitter gourd crop by plastic mulch: A profitable and sustainable technology for peri-urban area of northern India. ActaHorti, (ISHS) 731: 199-202.

Singh RM, Singh DK and Rao KVR, 2010. Fertigation for increased crop yield and fertilizer saving. Agricultural Engineering Today, Vol. 34(2), 2010.

\section{How to cite this article:}

Shelke, A. A., S. B. Wadatkar and Beldar, R. M. 2019. Effect of Different Levels of Fertilizer on Growth and Yield of Okra. Int.J.Curr.Microbiol.App.Sci. 8(12): 1363-1367. doi: https://doi.org/10.20546/ijcmas.2019.812.164 